\title{
Динаміка показників координаційних здібностей баскетболістів груп початкової підготовки під впливом використання спеціально-підготовчих вправ
}

\author{
Юрій Горчанюк \\ Максим Мерзлікін \\ Тамара Ляхова
}

Харківська державна академія фізичної культури, Харків, Україна

Мета: визначення ступеню впливу спеціально-підготовчих вправ на показники координаційних здібностей баскетболістів груп початкової підготовки.

Матеріал і методи: у дослідженні брали участь 40 спортсменів у віці 9-11 років, що навчаються в групах початкової підготовки другого року навчання ДЮСШ № 7 міста Харкова (контрольна група 20 спортсменів, експериментальна група 20 спортсменів). Для встановлення показників координаційної підготовленості юних баскетболістів використовувались стандартні тестові вправи, запропоновані Л.П. Сергієнко [13].

Результати: використовувалися у навчально-тренувальному процесі експериментальної групи спеціальнопідготовчих вправ: різноманітні стрибки та акробатичні вправи, а також комплекси вправ на батуті. Дана методика позитивно вплинула на показники координаційних здібностей баскетболістів групи початкової підготовки, і між результатами до та після педагогічного експерименту було встановлено достовірні розбіжності $(p<0,05)$.

Висновки: встановлено позитивну динаміку показників координаційних здібностей експериментальної групи після проведення педагогічного експерименту. Так, в тестуванні контролю оцінки і регуляції просторово-часових та динамічних параметрів рухів покращення результатів у відсотковому співвідношенні становило від 9\% до 43\%, в тестуванні оцінки відчуття часу приріст результатів коливався від 27\% до 56\%, поліпшення даних оцінки точності м'язових зусиль становило від 3\% до 16\%, динаміка показників контролю здібностей орієнтування у просторі склала від 7\% до 43\%, результати контролю стійкості статичної та динамічної рівноваги після педагогічного експерименту покращились з 14\% до 18\%, показники відчуття ритму змінились на 7\%, показники контролю здатності до довільного розслаблення м'язів покращились на 3\%, результати контролю координованості рухів було збільшено на $31 \%(p>0,05)$.

Ключові слова: спортсмени-баскетболісти, координаційні здібності, спеціально підібрані комплекси акробатичних вправ, вправи на батуті.

\section{Вступ}

Погіршення виступу українських баскетболістів на змаганнях різного рівня набуло в останній час стійкого характеру. Так, ще вісім років тому українські майстри помаранчевого м'яча входили до Топ-6 найкращих команд Європи. В сезоні 2020 найкращим результатом чоловічої збірної став лише вхід до Топ-16 команд Єврокубку.

Багато фахівців висловлюють свою думку з цього приводу. За даними Л. Ю. Поплавського, стрімке погіршення результатів пов'язано з помилками в керуванні командою під час змагань та у її комплектуванні [8].

Результати досліджень [5] свідчать про загальний низький рівень спортивно-педагогічного складу фахівців галузі, та, як наслідок, недоліки в підготовці спортивного резерву.
А. Тімофєєв зазначає, що дана ситуація пов'язана з проблемами фінансування дитячого та юнацького спорту [1].

Проте, на наш погляд, основним все ж таки є питання залучення до занять баскетболом найбільш талановитих юнаків та дівчат, розвинених фізично, з достатніми для гри в баскетбол антропометричними даними [11-14].

В системі фізичної підготовки юних баскетболістів особливе місце належить розвитку та вдосконаленню координаційних здібностей [6-9]. Розвинені координаційні здібності дозволяють юним спортсменам краще навчатися, точніше оцінювати просторові, тимчасові, динамічні параметри своїх рухів, точно і швидко виконувати рухові дії в незвичайних умовах, орієнтуватися в часі і в просторі, навіть передбачати зміни рухових дій, виконувати рухи ефективно та результативно [7]. 


\section{СЛОБОЖАНСЬКИЙ НАУКОВО-СПОРТИВНИЙ ВІСНИК}

Проблемі вивчення та вдосконалення координаційних здібностей різного контингенту людей в науковій та науково-методичній літературі було приділено достатньо уваги. В теорії і методиці фізичного виховання поглибленим вивченням розвитку та вдосконаленням координаційних здібностей різного контингенту дітей займались Круцевич Т.Ю. (2005), Лях В. І. (2006), Бала Т.М. (2015).

В спортивних іграх роботи Ю.А. Горчанюка (2016), О.К. Моісеєнко (2018), висвітлювали дане питання 3 точки зору вдосконалення окремих функцій аналізаторних систем. Дослідження О.О. Нессен (2017) експериментально підтвердили позитивну динаміку розвитку координаційних здібностей після впровадження в навчально-тренувальний процес гандболіств 13 - 14 років вправ складнокоординаційної спрямованості.

За результатами проведених досліджень [6], автором було розглянуто роль координаційних здібностей в системі підготовки кваліфікованих баскетболістів. В роботі було доведено їх вплив на результати виступу спортсменів в змаганнях різного рівня.

Проблемою вдосконалення різних видів координації юних баскетболістів займались І.П. Помещикова, Н.І.Чуча, Н.О. Пащенко [7 - 9].

Незважаючи на те, що проблемою розвитку та вдосконалення координаційних здібностей юних баскетболістів присвячено чимало робіт, багато питань є відкритими та потребують їх подальшого розгляду.

Метою нашого дослідження стало визначення ступеню впливу спеціально-підготовчих вправ на показники координаційних здібностей баскетболістів груп початкової підготовки.

\section{Матеріал і методи дослідження}

У роботі було використано наступні методи дослідження: теоретичний аналіз і узагальнення науково-методичної літератури, вивчення документальних матеріалів і педагогічне спостереження, педагогічне тестування, педагогічний експеримент, методи математичної статистики.

До педагогічного тестування було включено наступні тестові вправи, запропоновані Л. П. Сергієнко. Тестування координаційних здібностей проходило за показниками: човникового бігу 3 3x10 м з оббіганням набивних м'ячів (с), човникового бігу 4x9 м з веденням баскетбольного м'яча (с), стрибків на розмітку (см), передачі баскетбольного м'яча на швидкість і точність (с), тесту для оцінки балістичної координації рухів, помилки бігу на місці у середньому темпі 5 та 10 с, максимальної кистьової динамометрії правої та лівої руки, та диференціювання м язового зусилля 50 \% від максимуму (кг), кидків м'яча у ціль, стоячи до неї спиною (бали), оцінки просторової точності кутових рухів, у плечових та кульшових суглобах 450 та 900, статичної рівноваги за методикою Бондаревського (с), динамічної рівноваги при виконанні поворотів на гімнастичній лаві (с), спринту у заданому ритмі (c), здатності до довільного розслаблення м'язів (бали), комплексного контролю координованості рухів, оцінки результатів тесту «десять вісімок».

У дослідженні брали участь 40 спортсменів у віці 9-11 років. Із них 20 хлопчиків-баскетболістів, що навчаються в групах початкової підготовки другого року навчання ДЮСШ № 7 міста Харкова, які увійшли до контрольної групи, та 20 хлопчиків-баскетболістів, що навчаються в групах почат- кової підготовки другого року навчання ДЮСШ № 7 міста Харкова, які увійшли до експериментальної групи. Спортсмени, яких було залучено до участі в дослідженні, мали згоду батьків та навчались у різних тренерів-викладачів.

\section{Результати дослідження}

Впродовж чотирьох місяців навчально-тренувальний процес експериментальної групи було доповнено комплексами спеціальних вправ з акробатики, модифікованих рухливих ігор та спеціально підібраних вправ на батуті. В ході проведення педагогічного експерименту юним спортсменам поступово підвищували навантаження: збільшували дозування, складність і швидкість виконання вправ. Спеціально підібране навантаження змінювалося з урахуванням віку, фізичної підготовленості та індивідуальних особливостей спортсменів, які займалися. Спеціальні вправи було включено в підготовчу, основну та заключну частини заняття, що представлено в таблиці 1.

Впродовж 4 місяців тренувальний процес експериментальної групи було доповнено спеціально підібраними вправами, спрямованими на розвиток різних видів координації. Процес фізичної підготовки ускладнювався різноманітними стрибковими рухами, перекидами, перевертами, стійками, які виконувались як в основний, так і в зворотній бік, а також різноманітними вправами на батуті. Підбір навчального матеріалу було спрямовано на накопичення рухових навичок та розвитку спроможності до засвоєння та варіативного застосування техніки гри. Вправи на батуті спряли розвитку спеціальної стрибкової спритності. Тренувальний мікроцикл експериментальної групи представлено в таблиці 2.

Результати тестування координаційних здібностей баскетболістів експериментальної та контрольної груп після впровадження в навчально-тренувальний процес спеціально-підготовчих вправ представлені в таблиці 3.

Отримані результати координаційних здібностей контрольної та експериментальної груп після проведення педагогічного експерименту в тестуванні контролю здібності оцінки і регуляції просторово-часових та динамічних параметрів рухів, стрибків на розмітку та тесту для оцінки балістичної координації рухів, помилки відтворення кутових рухів у плечових суглобах (450), помилки відтворення кутових рухів у плечових суглобах (900), показників статичної та динамічної рівноваги показили достовірні розбіжності між результатами двох груп, і ці розбіжності суттєві та статистично достовірні $(p<0,05)$ (табл.3).

Між результатами тестування інших показників достовірних розбіжностей визначено не було $(p>0,05)$.

\section{Висновки / Дискусія}

Аналізуючи динаміку показників координаційних здібностей контрольної та експериментальної груп після проведення педагогічного експерименту встановлено, що вони покращились, і склали наступне: показники човникового бігу $3 \times 10$ м з оббіганням набивних м'ячів (с) - в контрольній групі покращились на 7\%, в експериментальній - на $9 \%(t=0,53 ; p>0,05)$; в результатах тестування човникового бігу $4 \times 9$ м 3 веденням баскетбольного м'яча (c) було встановлено зміни на 15\% в контрольній групі, та на 24\% в експериментальній групі (t=0,96; p>0,05); показники стрибків 
Таблиця 1

Додатковий навчальний матеріал для проведення педагогічного експерименту

\begin{tabular}{|c|c|c|c|}
\hline $\begin{array}{l}\text { № } \\
\text { 3.П. }\end{array}$ & Зміст навчального матеріалу & $\begin{array}{c}\text { Наванта- } \\
\text { ження }\end{array}$ & $\begin{array}{c}\text { Розподіл } \\
\text { навчального } \\
\text { матеріалу в } \\
\text { межах } \\
\text { річного } \\
\text { макроциклу }\end{array}$ \\
\hline 1. & $\begin{array}{l}\text { Акробатичні вправи. } \\
\text { Групування, стійки на лопатках, передпліччях і руках, } \\
\text { перекиди уперед, назад, Переворот колесом. «Міст». } \\
\text { Різновиди баскетбольних падінь, які поєднувались } 3 \\
\text { вище наведеними та імітаційними вправами. }\end{array}$ & Мале & $\begin{array}{c}\text { Загально- } \\
\text { підготовчий } \\
\text { етап }\end{array}$ \\
\hline 2. & $\begin{array}{l}\text { Стрибкові вправи. } \\
\text { Стрибки } 3 \text { різних вихідних положень, } 3 \text { просуванням } \\
\text { вперед, } 3 \text { обертами. Різновиди стрибків } 3 \\
\text { використанням гімнастичного містка. Стрибкові } \\
\text { вправи із завданнями (асиметрична робота рук та ніг). }\end{array}$ & Велике & $\begin{array}{c}\text { Загально- } \\
\text { підготовчий } \\
\text { етап }\end{array}$ \\
\hline 3. & $\begin{array}{l}\text { Вправи з використанням гімнастичного батуту. } \\
\text { Ходьба, заняття різних вихідних положень та їх } \\
\text { сполучення, невеликі стрибки по всій площині } \\
\text { батуту, темпові підскоки з поступовим підвищенням } \\
\text { висоти зльоту, після виконання різних за висотою } \\
\text { стрибків за завданням. Комплекси з вище наведених } \\
\text { вправ. }\end{array}$ & Середнє & $\begin{array}{c}\text { Загально- } \\
\text { підготовчий } \\
\text { етап }\end{array}$ \\
\hline 4. & $\begin{array}{l}\text { Модифіковані рухливі ігри. } \\
\text { Модіфіковані рухливі ігри та естафети. }\end{array}$ & Середнє & $\begin{array}{c}\text { Загально- } \\
\text { підготовчий } \\
\text { етап }\end{array}$ \\
\hline
\end{tabular}

Таблиця 2 другого року навчання на загальнопідготовчому етапі

\begin{tabular}{|c|c|l|c|c|}
\hline $\begin{array}{c}\text { День } \\
\text { заняття }\end{array}$ & $\begin{array}{c}\text { № } \\
\text { занятяя }\end{array}$ & \multicolumn{1}{|c|}{ Переважна спрямованість } & $\begin{array}{c}\text { Дозування } \\
\text { (хв.) }\end{array}$ & $\begin{array}{c}\text { Наванта- } \\
\text { ження }\end{array}$ \\
\hline Пн & 1 & $\begin{array}{l}\text { Удосконалення індивідуальної технічної } \\
\text { майстерності, різновиди передач. } \\
\text { Розвиток спеціальної гнучкості, } \\
\text { акробатичні вправи. Рухлива гра. }\end{array}$ & 90 & Мале \\
\hline Ср. & 2 & $\begin{array}{l}\text { Удосконалення швидкісно - силових } \\
\text { якостей та спеціальної спритності, вправи } \\
\text { на гімнастичному батуті. }\end{array}$ & 90 & Середнє \\
\hline Пн. & 3 & $\begin{array}{l}\text { Удосконалення індивідуальної технічної } \\
\text { майстерності, різновиди кидків. Розвиток } \\
\text { спеціальної гнучкості, акробатичні } \\
\text { вправи. Рухлива гра. }\end{array}$ & 90 & Мале \\
\hline Сб. & 4 & $\begin{array}{l}\text { Удосконалення індивідуальної технічної } \\
\text { майстерності, різновиди передач. } \\
\text { Розвиток швидкісно - силових якостей, } \\
\text { стрибкові вправи. Естафети. }\end{array}$ & 90 & Середнє \\
\hline
\end{tabular}


Таблиця 3

Показники координаційних здібностей баскетболістів контрольної та експериментальної груп після проведення педагогічного експерименту $(n=40)$

\begin{tabular}{|c|c|c|c|c|}
\hline \multirow[t]{2}{*}{ Рухові тести } & $\begin{array}{c}\text { КГ } \\
\text { після } \\
\text { експерименту } \\
(\mathbf{n}=\mathbf{2 0}) \\
\end{array}$ & $\begin{array}{c}\mathbf{E} \boldsymbol{} \\
\text { після } \\
\text { експерименту } \\
(\mathbf{n}=\mathbf{2 0})\end{array}$ & $\mathbf{t}$ & \multirow[t]{2}{*}{$\mathbf{p}$} \\
\hline & \multicolumn{2}{|c|}{$\bar{X} \pm m$} & & \\
\hline \multicolumn{5}{|c|}{$\begin{array}{c}\text { Контроль здібності оцінки і регуляції просторово - часових та динамічних } \\
\text { параметрів рухів }\end{array}$} \\
\hline $\begin{array}{l}\text { Човниковий біг } 3 \text { х10 м з оббіганням } \\
\text { набивних м’ячів (c) }\end{array}$ & $9,71 \pm 0,42$ & $9,31 \pm 0,62$ & 0,53 & $>0,05$ \\
\hline $\begin{array}{l}\text { Човниковий біг 4x ,14 м з веденням } \\
\text { баскетбольного м'яча (c) }\end{array}$ & $20,01 \pm 1,36$ & $18,47 \pm 0,85$ & 0,96 & $>0,05$ \\
\hline Стрибки на розмітку (см) & $9,21 \pm 0,91$ & $6,71 \pm 0,81$ & 2,08 & $<0,05$ \\
\hline $\begin{array}{l}\text { Передача баскетбольного } \\
\text { м’яча на швидкість і точність (с) }\end{array}$ & $29,41 \pm 2,11$ & $26,43 \pm 1,01$ & 1,27 & $>0,05$ \\
\hline $\begin{array}{l}\text { Тест для оцінки балістичної } \\
\text { координації рухів (см) }\end{array}$ & $1,01 \pm 0,43$ & $2,26 \pm 0,42$ & 2,08 & $<0,05$ \\
\hline \multicolumn{5}{|c|}{ Оцінка відчуття часу } \\
\hline $\begin{array}{l}\text { Помилка бігу на місці у середньому } \\
\text { темпі (5 c) }\end{array}$ & $1,41 \pm 0,42$ & $0,92 \pm 0,51$ & 0,74 & $>0,05$ \\
\hline $\begin{array}{l}\text { Помилка бігу на місці у середньому } \\
\text { темпі }(10 \text { c) }\end{array}$ & $1,76 \pm 0,51$ & $1,43 \pm 0,45$ & 0,49 & $>0,05$ \\
\hline \multicolumn{5}{|c|}{ Оцінка точності .м'язових зусиль } \\
\hline $\begin{array}{l}\text { Помилка відтворення } \\
\text { максимального зусилля (100% від } \\
\text { максимуму), права рука (кг) }\end{array}$ & $5,76 \pm 1,72$ & $5,54 \pm 1,43$ & 0,10 & $>0,05$ \\
\hline $\begin{array}{l}\text { Помилка відтворення } \\
\text { максимального зусилля (100% від } \\
\text { максимуму) ліва рука (кг) }\end{array}$ & $4,43 \pm 1,02$ & $4,23 \pm 1,51$ & 0,11 & $>0,05$ \\
\hline $\begin{array}{l}\text { Помилка відтворення } \\
\text { максимального зусилля (50 \% від } \\
\text { максимуму) права рука (кг) }\end{array}$ & $3,52 \pm 1,21$ & $3,13 \pm 1,02$ & 0,25 & $>0,05$ \\
\hline $\begin{array}{l}\text { Помилка відтворення } \\
\text { максимального зусилля (50 \% від } \\
\text { максимуму) ліва рука (кг) }\end{array}$ & $3,16 \pm 0,91$ & $3,24 \pm 1,62$ & 0,04 & $>0,05$ \\
\hline \multicolumn{5}{|c|}{ Контроль здібностей орієнтування у просторі } \\
\hline $\begin{array}{l}\text { Кидки м’яча у ціль, стоячи до неї } \\
\text { спиною (бали) }\end{array}$ & $7,74 \pm 1,33$ & $8,46 \pm 0,92$ & 0,45 & $>0,05$ \\
\hline $\begin{array}{l}\text { Помилка відтворення кутових рухів } \\
\text { у плечових суглобах }\left(45^{\circ}\right)\end{array}$ & $8,51 \pm 0,92$ & $5,12 \pm 1,21$ & 2,23 & $<0,05$ \\
\hline $\begin{array}{l}\text { Помилка відтворення кутових рухів } \\
\text { у плечових суглобах }\left(90^{0}\right)\end{array}$ & $8,11 \pm 1,12$ & $4,91 \pm 0,92$ & 2,21 & $<0,05$ \\
\hline $\begin{array}{l}\text { Помилка відтворення кутових рухів } \\
\text { у кульшових суглобах }\left(45^{0}\right)\end{array}$ & $7,45 \pm 1,34$ & $6,76 \pm 1,73$ & 0,32 & $>0,05$ \\
\hline $\begin{array}{l}\text { Помилка відтворення кутових рухів } \\
\text { у кульшових суглобах }\left(90^{0}\right)\end{array}$ & $9,43 \pm 1,12$ & $9,04 \pm 1,73$ & 0,19 & $>0,05$ \\
\hline
\end{tabular}


Продовження табл. 3

\begin{tabular}{|c|c|c|c|c|}
\hline \multicolumn{5}{|c|}{ Контроль стійкості рівноваги (статичної та динамічної) } \\
\hline $\begin{array}{l}\text { Статична рівновага за методикою } \\
\text { Бондаревського (з відкритими } \\
\text { очима)(c) }\end{array}$ & $22,47 \pm 2,01$ & $30,84 \pm 2,13$ & 2,86 & $<0,01$ \\
\hline $\begin{array}{l}\text { Динамічна рівновага при виконанні } \\
\text { поворотів на гімнастичній лаві (c) }\end{array}$ & $9,78 \pm 1,12$ & $7,14 \pm 0,62$ & 2,08 & $<0,05$ \\
\hline \multicolumn{5}{|c|}{ Контроль відчуття ритму } \\
\hline $\begin{array}{l}\text { Різниця спринту у заданому ритмі } \\
\text { (c) }\end{array}$ & $1,64 \pm 0,72$ & $1,45 \pm 0,43$ & 0,23 & $>0,05$ \\
\hline \multicolumn{5}{|c|}{ Показники здатності до довільного розслаблення м язів } \\
\hline $\begin{array}{l}\text { Здатність до довільного } \\
\text { розслаблення м’язів (бали) }\end{array}$ & $3,71 \pm 0,33$ & $3,91 \pm 0,21$ & 0,51 & $>0,05$ \\
\hline \multicolumn{5}{|c|}{ Контроль координованості рухів } \\
\hline $\begin{array}{l}\text { Комплексний контроль } \\
\text { координованості рухів, оцінка } \\
\text { результатів тесту «десять вісімок» }\end{array}$ & $14,34 \pm 1,83$ & $11,34 \pm 1,41$ & 1,30 & $>0,05$ \\
\hline
\end{tabular}

на розмітку змінились в бік покращення у відсотковому співвідношенні - у контрольній групі на 3\%, в експериментальній - на 43\% ( $t=2,08 ; p<0,05)$; зміни результатів передачі баскетбольного м'яча на швидкість і точність було зафіксовано на відмітці - у контрольній групі 14\%, в експериментальній - на 18\% (t=1,27; p>0,05); порівнюючи тестування оцінки балістичної координації рухів, встановлено двократне превалювання показників експериментальної групи над результатами контрольної; результати тестування бігу на місці у середньому темпі 5 с - в контрольній групі змінились на 22\%, в експериментальній - на 56\% ( $\mathrm{t}=2,08 ; \mathrm{p}<0,05)$; динаміка показників бігу на місці у середньому темпі 10 с була аналогічною - в контрольній групі відбулися зміни на 18\%, в експериментальній - на 27\% ( $\mathrm{t}=0,74$; p>0,05); зміни помилки відтворення максимального зусилля (100 \% від максимуму) правої руки після експерименту - в контрольній групі встановили 3\%, в експериментальній - результат повторився $(3 \%)(\mathrm{t}=0,10$; $p>0,05)$; динаміка показників помилки відтворення максимального зусилля (100 \% від максимуму) лівої руки - в контрольній групі склала - $2 \%$, в експериментальній - 5\% (t=0,11; $>>0,05)$; зміни помилки відтворення максимального зусилля (50 \% від максимуму) правої та лівої руки - в контрольній групі склали 11\% та $6 \%$, в експериментальній групі цей показник склав 5\% та $16 \%,(t=0,25 ; p>0,05)$ та $(t=0,04 ; p>0,05)$ відповідно.

Аналіз показників контролю здібностей орієнтування у просторі за показниками кидків м'яча у ціль, стоячи до неї спиною, свідчить, що в контрольній групі вони склали 4\%, в експериментальній 15\% ( $t=0,45 ; p>0,05)$; у відтворенні кутових рухів у плечових суглобах (450) помилка зменшилась - в контрольній групі на 8\%, в експериментальній на 42\% (t=2,23; $p<0,05)$; аналогічна тенденція спостерігалася в тестуванні помилки відтворення кутових рухів у плечових суглобах (900). Так, у контрольній групі ці зміни склали 16\%, в експериментальній 43\% $(\mathrm{t}=2,21 ; \mathrm{p}<0,05)$; відтворення кутових рухів у кульшових суглобах (450) учасникам тестування вдалося поліпшити, в контрольній групі на 9\%, в експериментальній - на 13\% ( $t=0,32 ; p>0,05)$; при відтворенні кутових рухів у кульшових суглобах (900) помилка зменшилась - в контрольній групі на 5\%, в експериментальній - на 7\% $(\mathrm{t}=0,19 ; \mathrm{p}>0,05) ;$ покращення показників статичної рівноваги за методикою Бондаревського - в контрольній групі склало 6\%, в експериментальній - 14\% ( $\mathrm{t}=2,86$; $\mathrm{p}<0,01)$; динамічна рівновага при виконанні поворотів на гімнастичній лаві змінилась - в контрольній групі на $4 \%$, в експериментальній - на 18\% ( $t=2,08 ; p<0,05)$; зміни показників спринту у заданому ритмі встановили - в контрольній групі 6\%, в експериментальній - 7\% ( $\mathrm{t}=0,23$; p>0,05); здатність до довільного розслаблення м'язів покращилась - в контрольній і експериментальній групі на 3\% ( $t=0,51 ; p>0,05)$; результати контролю координованості рухів за показниками оцінки тесту «десять вісімок» покращились в контрольній групі на 14\%, в експериментальній - на 31\% (t=1, 30; p>0,05).

Аналіз літературних джерел свідчить про те, що дана проблема не $є$ новою. Впровадження в навчально-тренувальний процес волейболістів-початківців спеціально-підібраних комплексів вправ на координаційній драбині сприяло як покращенню показників координаційних здібностей, так і опосередковано вплинуло на результати фізичної підготовленості учнів-спортсменів [4].

За результатами, отриманими О.О. Биковою, комплексами спеціально-підібраних вправ було покращено показники координованості гандболістів груп базової підготовки [3].

Таким чином, проведений аналіз статистичного матеріалу встановив, що досліджувані показники контролю здібності оцінки і регуляції просторово-часових та динамічних параметрів рухів, здібності орієнтування у просторі, стійкості статичної та динамічної рівноваги, контролю відчуття ритму, здатності до довільного розслаблення м'язів та контролю координованості рухів після впровадження в навчально-тре- 


\title{
СЛОБОЖАНСЬКИЙ НАУКОВО-СПОРТИВНИЙ ВІСНИК
}

нувальний процес юних баскетболістів комплексів вправ складнокоординаційної спрямованості покращились, і за показниками тестування стрибків на розмітку, тесту для оцінки балістичної координації рухів, помилки відтворення кутових рухів у плечових суглобах (450 та 900), результати експериментальної групи превалюють над такими контрольної.
Порівнюючи отримані показники після педагогічного експерименту з результатами Л.П. Сергієнко встановлено їх покращення.

Перспективи подальших досліджень. У перспективі в даному напрямку цікавим $€$ визначення впливу системи спеціальних складнокоординаційних вправ на показники фізичної підготовленості юних баскетболістів.

Конфлікт інтересів. Автори заявляють, що відсутній конфлікт інтересів, який може сприйматись таким, що може завдати шкоди неупередженості статті.

Джерела фінансування. Ця стаття не отримала фінансової підтримки від державної, громадської або комерційної організації.

\section{Список посилань}

1. Тімофєєв А. (2018). «Порівняння показників фізичної та технічної підготовленості баскетболістів 12 і 13 років», Слобожанський науково-спортивний вісник, № 1, С. 98-101.

2. Бала Т. М. (2015), «Вплив вправ чирлідингу на координаційні здібності школярів 5-9-х класів», Слобожанський науковоспортивний вісник, № 5, С. 24-28.

3. Бикова О. О. (2016). «Зміни здатності гандболістів 13 - 14 років координувати рухи за просторово - часовими та динамічними параметрами під впливом спеціально - підібраних вправ», Спортивний вісник Придніпров'я, Вип. 2, № 2, С. 25-29.

4. Горчанюк Ю. А. (2020). «Зміни показників фізичної підготовленості волейболістів 9 -11 років під впливом спеціальнопідібраних комплексів вправ», Науковий часопис НПУ імені М.П. Драгоманова. Серія 15: Науково-педагогічні проблеми фізичної культури (фізична культура і спорт) : зб. наук. праць. Київ : Вид-во НПУ імені М. П. Драгоманова, Випуск 5 (125) 20, С. 54 - 63.

5. Круцевич Т. Ю., Воробйов М. І. (2005), Контроль у фізичному вихованні дітей, підлітків та юнацтва : навчальний посібник для студентів ф-тів фіз. культури, Київ, 196 с.

6. Криворучко Н. В., Масляк І. П. (2016), «Шляхи підвищення фізичного розвитку та фізичної підготовленості молодого покоління", Науковий часопис Національного педагогічного університету імені М. П. Драгоманова. Серія 15 : Науково-педагогічні проблеми фізичної культури (фізична культура і спорт) : зб. наук. праць. Київ : Вид-во НПУ імені М. П. Драгоманова, Вип. 11(81). С. 57-60.

7. Лях В. И. (2006), Координационные способности: диагностика и развитие: уч. пособ. Москва: ТВТ Дивизион, 290 с.

8. Поплавський Л. Ю. (2004), Баскетбол: підр. для студ. вищих навч. закладів фіз. вих. і спорту. Київ: Олімпійська література, 446 c.

9. Помещикова І., Чуча Н., Чуча Ю., Кудімова, О. (2020). «Зміни показників координаційних здібностей баскетболістів студентської команди під впливом спеціально підібраних вправ з м'ячами», Спортивні ігри, № 2 (16), С. 58-68. https://doi: 10.15391/si.2020-2.06

10. Помещикова І. П., Пащенко Н. О. (2016), «Стан координаційних здібностей баскетболістів студенської команди», Фізична культура, спорт та здоров'я: стан, проблеми та перспективи: матеріали XVI Міжнародної науково-практичної конференції. Харків: ХДАФК, С. 193-196.

11. Помещикова І. П., Пащенко Н. О., Ширяєва І. В., Кудімова О. В. (2021), «Зміни показників рівноваги баскетболістів 12 років під впливом вправ на балансувальній півсфері», Спортивні ігри, №. 2 (20), С. 83-91. https://doi: 10.15391/si.2021-2.08

12. Приймаков А. А., Козеток И. И. (2000), «Закономерности развития координационных движений у детей 7-9 лет», Наука в олимпийском спорте, №1, С. 53-59.

13. Сергиенко Л. П. (2001), Тестування рухових здібностей школярів: навчальний посібник для студентів ф-тів фіз. культури. Київ, 430 с.

14. Spencer M. (2011), Mini Basketball. A guide to teaching and coaching. Written and Compiled By Martin Spencer. 255 p.

15. Bompa T.O., Carrera M. (2005), Periodization training for sports. Chapmaign, Human Kinetics, 259 p.

16. Zollner M. (2004), «Mini-basketball Program in Berlin. Minibasketball, school games and activities», Fiba assist magazine, № 10, pp. 63-65.

17. Deshon D. A (2006) «Cinematographies analysis of sprint running». Res. Quart. № 7, pp. 124-127.

Стаття надійшла до редакції: 14.05.2021 р.

Опубліковано: 23.06.2021 p.

\begin{abstract}
Аннотация. Юрий Горчанюк, Максим Мерзликин, Тамара Ляхова. Динамика показателей координационных способностей баскетболистов групп начальной подготовки под влиянием использования специально- подготовительных упражнений. Цель: определение степени влияния специально-подготовительных упражнений на показатели координационных способностей баскетболистов групп начальной подготовки. Материал и методы: в исследовании принимали участие 40 спортсменов в возрасте 9 - 11 лет, обучающихся в группах начальной подготовки второго года обучения ДЮСШ № 7 города Харькова (контрольная группа 20 спортсменов, экспериментальная группа 20 спортсменов). Для установления показателей координационной подготовленности юных баскетболистов использовались стандартные тестовые упражнения, предложенные Л.П. Сергиенко [13]. Результаты: использовались в учебно-тренировочном процессе экспериментальной группы специальноподготовительные упражнения: различные прыжки и акробатические упражнения, а также комплексы упражнений на батуте. Данная методика положительно повлияла на показатели координационных способностей баскетболистов группы начальной подготовки, и между результатами до и после педагогического эксперимента было установлено достоверные различия ( $p<0,05)$. Выводы: установлено положительную динамику показателей координационных способностей экспериментальной группы после проведения педагогического эксперимента. Так, в тестировании контроля оценки и регуляции пространственно-временных
\end{abstract}


и динамических параметров движений улучшение результатов в процентном соотношении составило от 9\% до 43\%, в тестировании оценки ощущение времени прирост результатов колебался от 27\% до 56\%, улучшение данных оценки точности мышечных усилий составило от 3\% до 16\%, динамика показателей контроля способностей ориентирования в пространстве составила от $7 \%$ до 43\%, результаты контроля устойчивости статического и динамического равновесия после педагогического эксперимента улучшились с 14\% до 18\%, показатели чувства ритма изменились на 7\%, показатели контроля способности к произвольному расслаблению мышц улучшились на 3\%, результаты контроля координированности движений были увеличены на 31\% (р <0,05).

ключевые слова: спортсмены-баскетболисты, координационные способности, специально подобранные комплексы акробатических упражнений, упражнения на батуте.

\begin{abstract}
Yuri Gorchanyuk, Maxim Merzlikin, Tamara Lyakhova. Dynamics of indicators of coordination abilities of basketball players of groups of initial training under the influence of the use of special preparatory exercises. Purpose: to determine the degree of influence of special preparatory exercises on indicators of coordination abilities of basketball players of initial preparation groups. Material and methods: the study involved 40 athletes aged 9 - 11 years, that are part of initial training groups of the second year of study in the sports school № 7 in Kharkiv (control group 20 athletes, experimental group 20 athletes). To establish the indicators of coordination readiness of young basketball players, the standard test exercises proposed by L.P. Sergienko [13] were used. Results: in the training process of the experimental group of special - preparatory exercises were used: various jumps and acrobatic exercises, as well as sets of exercises on a trampoline. This technique had a positive effect on the coordination abilities of basketball players in the initial training group, and significant differences were found between the results before and after the pedagogical experiment $(p<0,05)$. Conclusions: the positive dynamics of coordination abilities indicators of the experimental group is established after the pedagogical experiment. Thus, in testing the control of evaluation and regulation of spatio-temporal and dynamic parameters of movements, the improvement of results in percentage was from $9 \%$ to $43 \%$, in testing the evaluation of sense of time the increase in results ranged from $27 \%$ to $56 \%$, improvement of muscle accuracy efforts ranged from $3 \%$ to $16 \%$, the dynamics of indicators of control of spatial orientation was from $7 \%$ to $43 \%$, the results of control of stability of static and dynamic balance after the pedagogical experiment improved from $14 \%$ to $18 \%$, indicators of sense of rhythm changed by $7 \%$, indicators of control of the ability to arbitrarily relax muscles improved by $3 \%$, the results of control of coordination of movements were increased by $31 \%(p>0.05)$.
\end{abstract}

Keywords: basketball athletes, coordination abilities, specially selected sets of acrobatic exercises, trampoline exercises.

\title{
References
}

1. Timofieiev, A. (2018), "Comparison of indicators of physical and technical fitness of basketball players aged 12 and 13 », Slobozhanskyi naukovo-sportyvnyi visnyk, No. 1, pp. 98-101. (in Ukr.)

2. Bala, T. M. (2015), «The influence of cheerleading exercises on the coordination abilities of students in grades 5-9», Slobozhanskyi naukovo-sportyvnyi visnyk, naukovo-. sportyvnyi visnyk, No. 5, pp. 24-28. (in Ukr.)

3. Bykova, O. O. (2016), «Changes in the ability of handball players aged 13 - 14 to coordinate movements according to spatial - temporal and dynamic parameters under the influence of specially selected exercises», Sportyvnyi visnyk Prydniprov ya, Vyp. 2, No. 2, pp. 25-29. (in Ukr.)

4. Horchaniuk, Yu. A. (2020), «Changes in indicators of physical fitness of volleyball players of 9 -11 years under the influence of specially selected sets of exercises», Naukovyi chasopys NPU imeni M.P. Drahomanova NCh. Seriia 15 : Naukovo-pedahohichni problemy fizychnoi kultury (fizychna kultura i sport) : zb. nauk. prats. Kyiv: Vyd-vo NPU imeni M. P. Drahomanova, Vypusk 5(125) 20, pp. 54-63. (in Ukr.)

5. Krutsevych, T. Yu., Vorobiov, M. I. (2005), Kontrol u fizychnomu vykhovanni ditei, pidlitkiv ta yunatstva : navchalnyi posibnyk dlia studentiv f-tiv fiz. kultury, Kyiv, 196 p. (in Ukr.)

6. Kryvoruchko, N. V., Masliak, I. P. (2016), «Ways to increase the physical development and physical fitness of the younger generation», Naukovyi chasopys Natsionalnoho pedahohichnoho universytetu imeni M. P. Drahomanova. Seriia 15 : Naukovopedahohichni problemy fizychnoi kultury (fizychna kultura i sport) : zb. nauk. prats. Kyiv : Vyd-vo NPU imeni M. P. Drahomanova, Vyp. 11(81). pp. 57-60. (in Ukr.)

7. Liakh, V. Y. (2006), Koordynatsyonnыe sposobnosty: dyahnostyka y razvytye: navch. posib., Moskva, TVT Dyvyzyon, 290 p. (in Russ.)

8. Poplavskyi, L. Iu. (2004), Basketbol: pidr. dlia stud. vyshchykh navch. zakladiv fiz. vykh. i sportu. Kyiv: Olimpiiska literatura, 446 p. (in Ukr.)

9. Pomeshchykova, I., Chucha, N., Chucha, Yu., Kudimova, O. (2020), «Changes in indicators of coordination abilities of basketball players of the student team under the influence of specially selected exercises with balls», Sportyvni ihry, No. 2 (16), pp. 5868. https://doi: 10.15391/si.2020-2.06 (in Ukr.)

10. Pomeshchykova, I. P., Pashchenko, N. O. (2016), «The state of coordination abilities of basketball players of the student team», Fizychna kultura, sport ta zdorovia: stan, problemy ta perspektyvy: materialy XVI Mizhnarodnoi naukovo-praktychnoi konferentsii, Kharkiv, pp. 193-196. (in Ukr.)

11. Pomeshchykova, I. P., Pashchenko, N. O., Shyriaieva, I. V., Kudimova, O. V. (2021), "Changes in the balance of basketball players 12 years under the influence of exercises in the balancing hemisphere», Sportyvni ihry, No. 2 (20), pp. 83-91. https://doi: 10.15391/si.2021-2.08 (in Ukr.)

12. Serhyenko, L. P. (2001), Testuvannia rukhovykh zdibnostei shkoliariv: navchalnyi posibnyk dlia studentiv f-tiv fiz. kultury. Kyiv, 430 p. (in Ukr.)

13. Pryimakov, A. A., Kozetok, Y. Y. (2000), «Zakonomernosty razvytyia koordynatsyonnbkh dvyzhenyi u detei 7-9 let», Nauka v olympyiskom sporte, №1, S. 53-59. (in Ukr.)

14. Spencer, M. (2011), Mini Basketball. A guide to teaching and coaching. Written and Compiled By Martin Spencer. 255 p. (in Eng.)

15. Bompa, T.O., Carrera, M. (2005), Periodization training for sports. Chapmaign, Human Kinetics, 259 p. (in Eng.)

16. Zollner, M. (2004), «Mini-basketball Program in Berlin. Minibasketball, school games and activities», Fiba assist magazine, № 10 , pp. 63-65. (in Eng.)

17. Deshon, D. A (2006) «Cinematographies analysis of sprint running». Res. Quart. № 7, pp. 124-127. (in Eng.)

Received: 14.05.2021.

Published: 23.06 .2021 


\section{СЛОБОЖАНСЬКИЙ НАУКОВО-СПОРТИВНИЙ ВІСНИК}

\section{Відомості про авторів / Information about the Authors}

Горчанюк Юрій Андрійович: к.фіз.вих., доцент; Харківська державна академія фізичної культури: вул. Клочківська, 99, м. Харків, 61058, Україна.

Горчанюк Юрий Андреевич: к.физ.восп., доцент; Харьковская государственная академия физической культуры: ул. Клочковская, 99, г. Харьков, 61058, Украина.

Yuri Gorchanyuk: Candidate of Sciences in Physical Education and Sports; Kharkiv State Academy of Physical Culture: Klochkivskaya, 99, Kharkiv, 61058, Ukraine.

ORCID: https://orcid.org/0000-0001-7158-3061

E-mail: gorchan.pl@gmail.com

Мерзлікін Максим Вікторович: викладач кафедри спортивних та рухливих ігор; Харківська державна академія фізичної культури: вул. Клочківська, 99, м. Харків, 61058, Україна.

Мерзликин Максим Викторович: преподаватель кафедры спортивних и подвижных игр; Харьковская государственная академия физической культуры: ул. Клочковская, 99, г. Харьков, 61058, Украина.

Maxim Merzlikin: teacher of the department of sports and mobile games; Kharkiv State Academy of Physical Culture: Klochkivskaya, 99, Kharkiv, 61058, Ukraine.

ORCID: https://orcid.org/0000-0002-6819-971X

E-mail: merzlikin80@mail.ua

Ляхова Тамара Петрівна: старший викладач кафедри спортивних та рухливих ігор; Харківська державна академія фізичної культури: вул. Клочківська, 99, м. Харків, 61058, Україна.

Ляхова Тамара Петровна: старший преподаватель кафедры спортивних и подвижных игр; Харьковская государственная академия физической культуры: ул. Клочковская, 99, г. Харьков, 61058, Украина.

Tamara Lyakhova: senior lecturer of the department of sports and mobile games; Kharkiv State Academy of Physical Culture: Klochkivskaya, 99, Kharkiv, 61058, Ukraine.

ORCID: https://orcid.org/0000-0003-4853-0513

E-mail: tamaraliahova29@gmail.com 